\title{
First record of Caecilia guntheri Dunn, 1942 (Gymnophiona, Caeciliidae) in Central America
}

\author{
Luis C. Elizondo-Lara
}

Programa de Maestría en Ciencias Biológicas, Vicerrectoría de Investigación y Postgrado, Universidad de Panamá, Panama City, Panama • luis. elizondo@up.ac.pa; elizondolui@gmail.com (1) https://orcid.org/0000-0002-8647-6717

Departamento de Fisiología y Comportamiento Animal, Facultad de Ciencias Naturales Exactas y Tecnología, Universidad de Panamá, Panama City, Panama

Red Mesoamericana y del Caribe para la Conservación de Anfibios y Reptiles

\begin{abstract}
I report the first encounter in Central America of an individual of Caecilia guntheri Dunn, 1942 (Gymnophiona, Caeciliidae). The individual was observed and collected in a primary evergreen submontane forest in Cerro Pirre, Darien Province, Republic of Panama. It was identified mainly by the low counts of secondary and primary folds. The encounter of this individual of $C$. guntheri highlights the disjunct populations and apparently the results of dispersion of this species from South to Central America by biotic exchange as result of the closure of the Isthmus of Panama.
\end{abstract}

\section{Keywords}

Amphibians, biotic exchange, Cerro Pirre, Darien, disjunct distribution, Panama

Academic editor: Javier Ernesto Cortés Suárez | Received 28 December 2020 | Accepted 28 March 2021 | Published 13 April 2021

Citation: Elizondo-Lara LC (2021) First record of Caecilia guntheri Dunn, 1942 (Gymnophiona, Caeciliidae) in Central America. Check List 17 (2): 649-653. https://doi.org/10.15560/17.2.649

\section{Introduction}

The genus Caecilia Linnaeus, 1758 was described from South America specimens and contains the largest number of caecilian species in the New World (Wilkinson and Nussbaum 2006; Wilkinson et al. 2011). Only four species of Caecilia are currently known from Central America, and their ancestors are thought to have reached that region after the Pliocene closure of the Isthmus of Panama (Savage and Wake 2001). Three species, C. isthmica Cope, 1877, C. leucocephala Taylor, 1968, and C. nigricans Boulenger, 1902, are known to occur in Darien Province, Panama, and have ranges extending into the Chocó region of northwestern South America, whereas the fourth species, C. volcani Taylor, 1969, occurs in central and northwestern Panama and in southeastern Costa
Rica (Köhler 2011; Kubicki and Arias 2017).

All fossorial caecilians are very difficult to find, and many of them are known from only a few localities, which leads to difficulties for improving the knowledge about their basic biology and biogeography. Herein, I report the occurrence of a specimen identified as Caecilia guntheri Dunn, 1942 from Cerro Pirre (CP) in the Serranía de Pirre (SP), Parque Nacional Darién (PND), Panama, close to the border between Panama and Colombia. Caecilia guntheri was previously known from the Pacific slopes of the Andes in Ecuador and the western slopes of the Western Cordillera and Eastern Cordillera of the Colombian Andes within an altitudinal range from 70 to $1800 \mathrm{~m}$ (Lynch 1999; Mueses-Cisneros and 
Moreno-Quintero 2012; Arteaga et al. 2013). This novel record extends the known geographic range of $C$. guntheri to the northern end of the Choco biogeographic province (Morrone 2006) in eastern Panama, Central America. It seems the result of a dispersion event from South to Central America.

\section{Methods}

I carried out fieldwork in CP during February and August 2014 to assess the ecological condition of mature forests on this mountain. Six transects of $400 \times 2 \mathrm{~m}$ were sampled twice per day, once during the daytime and once at night. The specimen was immediately collected it by hand and kept alive for seven days until my return to the laboratory of the Museo de Vertebrados de la Universidad de Panamá (MVUP), University of Panama. The specimen was collected under a permit provided by the Ministerio de Ambiente de Panamá (SE/AP-10-14).

In the laboratory, the specimen was photographed using a Canon EOS Rebel T100 camera, euthanized by freezing, fixed in 5\% formalin solution, and preserved in $70 \%$ ethanol. It was deposited in the MVUP.

Laboratory observations were made with the naked eye or aided by a Leica M80 stereoscopic microscope mounted with a Leica DFC295 camera for detailed photographs. Identification of the species is based mainly by counting the number of primary and secondary folds and by using the keys and descriptions by Dunn (1942), Taylor (1968), Lynch (1999), Savage and Wake (2001), and Köhler (2011). The primary folds are identified as the folds starting immediately after the two nuchal collars, and the secondary folds are those folds following the first secondary groove. Details to identify primary and secondary folds are provided by Lynch (1999) and Köhler (2011).

The map (Fig. 1) was prepared using DIVA-GIS 7.5.0 (Hijmans et al. 2012) with country-level data of administrative areas and elevation (at 3" resolution) included for Ecuador, Colombia, and Panama.

\section{Results}

\section{Caecilia guntheri Dunn, 1942}

New record. Panamá - Darién • Pinogana District, El Real, Pijibasal, Cerro Pirre; 0759'47"N, 077² $42^{\prime} 42^{\prime \prime} \mathrm{W}$; 620 m a.s.1.; 22.VIII.2014; Luis Carlos Elizondo-Lara leg.; 1 adult, MVUP 2665.

The specimen was found crawling on the floor of an evergreen submontane forest during a heavy rain at dawn (1820 h).

Identification. The specimen has 127 primary folds with the last 30 complete (Fig. 2A) and seven incomplete secondary folds (Table 1; Fig. 2B). The specimen lacks a tail, but a terminal shield is defined by the last eight primary fold and the secondary folds. The vent is transversely oriented and has 15 anal denticulations

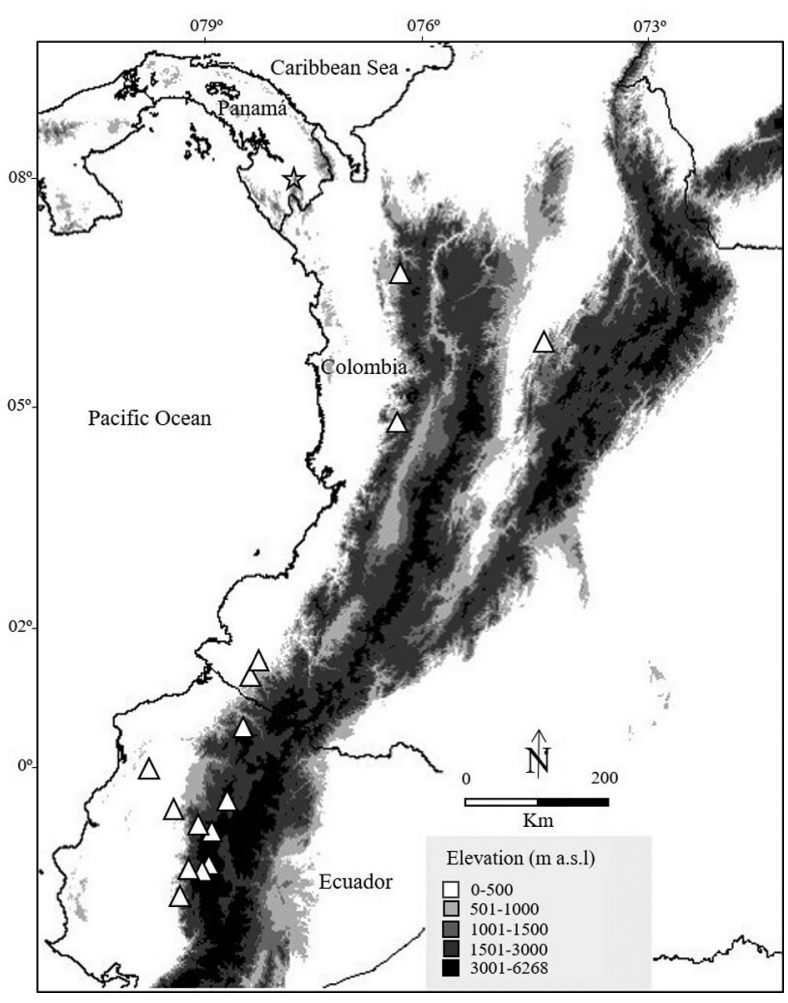

Figure 1. Distribution of C. guntheri in the Neotropics. Star indicates specimen MVUP 2665 from Serranía de Pirre, Darien, Panama, Central America. Triangles are records from Colombia and Ecuador. Data from Colombia and Ecuador are adapted from Lynch (1999), Mueses-Cisneros and Moreno-Quintero (2012), and Arteaga et al. (2013).

(AD), four anterior, five posterior, and three to each side (Fig. 2C). As typical for Caecilia, the sensory tentacle is located immediately and posterioventral to the nostril and closer to the nostril than the eye (Fig. 3).

Measurements were: SVL $396 \mathrm{~mm}$; diameter at midbody $10.4 \mathrm{~mm}$; ratio of length/diameter (1/d) 38; distance from tentacle to nostril $2.0 \mathrm{~mm}$; distance from tentacle to eye $4.5 \mathrm{~mm}$; distance from nostril to eye $4.5 \mathrm{~mm}$; head length from tip of snout to first primary fold $19 \mathrm{~mm}$, to second primary fold $21.5 \mathrm{~mm}$, to third primary fold 23.9, to first nuchal collar $12.5 \mathrm{~mm}$, to second nuchal collar $14.7 \mathrm{~mm}$; distance between eyes $5 \mathrm{~mm}$, between narial plugs $2.5 \mathrm{~mm}$, head width measured at the start of the mouth $7.5 \mathrm{~mm}$. Projection of snout from anterior edge of superior lip to tip of snout $1.8 \mathrm{~mm}$, from first nuchal collar to tip of snout (or also head length) $12.3 \mathrm{~mm}$.

Dentition consisted of four series: 1) premaxillarymaxillary (premaxillaries 3-1-3 and maxillaries 8-8); 2) vomeropalatine 11-1-10 (vomers 2-1-2 and maxilopalatines 9-8); 3) dentary 9-9; 4) splenial 1-2. Series 1, 2, and 3 with enlarged anterior teeth (those on premaxillary, vomer, and dentary huge) and decreasing in size posteriorly. Teeth on anterior dentaries are larger than those on premaxillaries and strongly recurved (hooked). There are two narial plugs in the anterior distal edge of the tongue.

In life, the dorsal color was dark purplish, but after four days alive in a plastic bag, the caecilian's dorsum became dark grayish. The head was always somewhat 


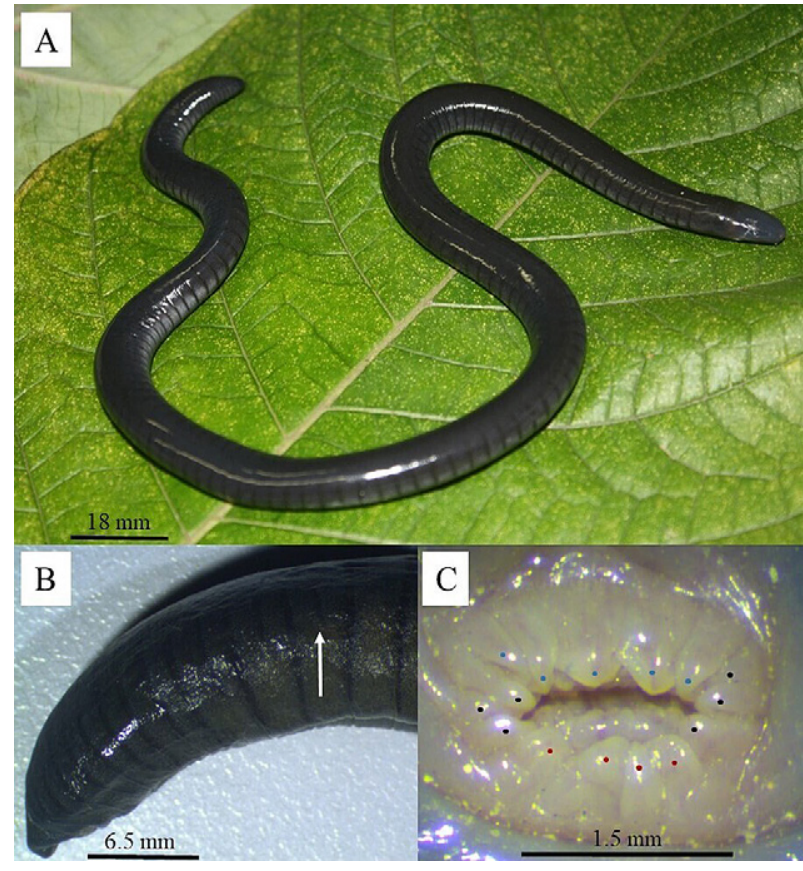

Figure 2. Caecilia guntheri from Cerro Pirre (MVUP 2665). A. Dorsal view in life. B. Lateral view of posterior and distal region of the body in preservative, the white arrow points to the first secondary groove dividing primary fold and the first secondary fold. $\mathbf{C}$. frontal view of vent in preservative, there are five posterior (blue dots) four anterior (red dots) and three lateral (black dots) denticulations.

lighter colored than the body. The venter was light grayish, in contrast to the dark colored incomplete primary folds. In preservative, the dorsum is dark gray and the ventral surface turned brownish but remained lighter than the dorsum.

Distinction from similar species. Caecilia guntheri has low numbers of primary and mainly secondary fold counts (see Dunn 1942; Taylor 1968; Lynch 1999; Wilkinson and Nussbaum 2006). In the most recent review of Colombian caecilians, Lynch (1999) characterized the species as having 108-132 primary folds and 7-28 secondary folds (Table 1). Lynch's (1999) data clearly distinguish $C$. guntheri, and the specimen from $\mathrm{CP}$ understood here as $C$. guntheri, from two other species in South America having low primary and secondary fold counts, C. subnigricans Dunn, 1942 (151-161 primaries, 9-31 secondaries) from northern Colombia

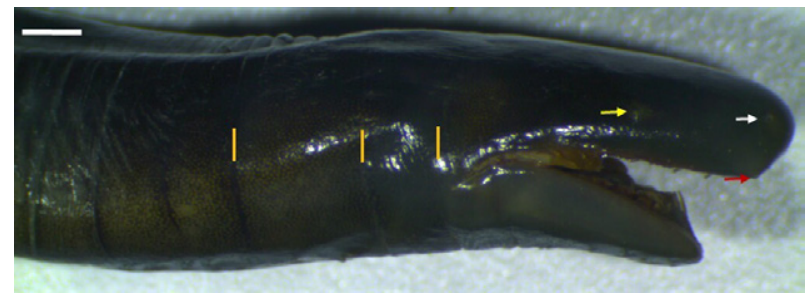

Figure 3. Lateral view of the head for the specimen of Caecilia guntheri from Serranía de Pirre. White bar represents $2 \mathrm{~mm}$ length, yellow lines represent nuchal folds of nuchal collars; yellow, white, and red arrows indicate respectively the eye socket, the nostril plugs, and the sensory tentacle.

and northern Venezuela, and C. abitaguae Dunn, 1942 (143-147 primaries, 3-6 secondaries) from eastern Ecuador (Table 1). The secondary folds also distinguish the Panamanian specimen from $C$. tentaculata Linnaeus, 1758 , another more broadly distributed species in South America which originally was though occurring also in eastern Panama (Dunn 1942; Taylor 1968). Later, this eastern Panamanian population of "C. tentaculata", along with some populations in the Pacific vertant of Colombia were reevaluated and identified as $C$. isthmica. In all treatments, historically and recently, C. tentaculata has been described with high count of secondary folds. Taylor (1968) redescribed the holotype of C. tentaculata as having 35 secondary folds. For the number of secondary folds in C. tentaculata, Nussbaun and Hoogmoed (1979) gave the range as 28-32 for specimens from Suriname, and Taylor $(1973 ; 1974)$ gave the range as $23-62$ in specimens from Ecuador. Lynch (1999) gave a range of 18-28 secondary folds for specimens from Andean forests of Colombia, and between 31-33 from Colombian Amazonia. Maciel and Hoogmoed (2011) gave a range of 23-43 secondary folds from Brazilian Amazonia. Some individuals studied by Dunn (1942) had a low count of secondary folds, between $12-37$; these individuals were originally identified as $C$. tentaculata but are now recognized as $C$. isthmica.

Counts of secondary folds also distinguish C. guntheri, and the specimen from $\mathrm{CP}$, from two Central American species, C. leucocephala (32-54 secondaries) from southeastern Panama through western Colombia to western Ecuador, and C. nigricans (42-62 secondaries) of

Table 1. Primary and secondary fold ranges for Central and South American Caecilia species with low count in secondary folds. Asterisks denotes linkage in fold counts.

\begin{tabular}{|c|c|c|c|}
\hline Regional account of taxa & Primary folds & Secondary folds & Total folds \\
\hline \multicolumn{4}{|c|}{ South Americans Caecilia species with low count in secondary folds } \\
\hline C. subnigricans & $151-161$ & $9-31$ & 151-196 \\
\hline C.abitague & $143-147$ & $3-6$ & $?$ \\
\hline C. guntheri & $108-132$ & $7-28$ & $115-154$ \\
\hline \multicolumn{4}{|l|}{ Central Americans Caecilia species } \\
\hline C. nigricans & $150-188$ & $42-62$ & $196-252$ \\
\hline C. leucocephala & $118-131$ & $32-54$ & $150-185$ \\
\hline C. isthmica & $131-147$ & $12-21$ & $143-168$ \\
\hline C. volcani & $112-124$ & $14-37$ & $126-156$ \\
\hline Caecilia guntheri* (MVUP 2665), new record from Panama & 127 & 7 & 134 \\
\hline
\end{tabular}


southeastern Panama through western Colombia, northwestern Ecuador, and Caribbean drainage in Colombia and Venezuela (Table 1). However, there is overlap in the accepted number of fold counts for $C$. guntheri and two similar southern Central American species. There are overlapping values in the lower limits of primary and median values of secondary folds of $C$. isthmica (131147 primaries, 12-21 secondaries). Also overlapping in median values of primary folds and median and upper values of secondary folds in C. volcani (112-124 primaries and 14-37 secondaries) (Table 1). The counts of primary and the secondary folds of the CP specimen fall well within the limits for $C$. guntheri and outside of the overlapping ranges of fold count limits in both $C$. isthmica and $C$. volcani; thus, I identify it as $C$. guntheri (Table 1).

Other traits, such as tentacle-nostril distance, distance between eyes (Taylor (1968) considered head width), and length from tip of snout to second nuchal fold are in accordance with the redescription of the type specimen by Taylor (1968), and these reinforce my identification of the CP specimen as C. guntheri. Additionally, the dental formula is very similar to the formula for the type specimen of C. guntheri as described by Taylor (1968, numbers in parentheses from Taylor): pre-maxillaries 11-1-11 (12-1-12), vomer palatines 11-1-10 (11-1-11), dentaries 9-9 (11-11), splenius 1-2 (?-2). The variation exhibited may be due to the loss and replacement of teeth, which result in marked variation in dentition in Caecilia (Taylor 1968; Dunn 1942), which is well exemplified in the description of other species of the genus (Taylor 1969).

Anal denticulation also are considered as a meristic trait of caecilian species. However, this trait shows overlap among most species of Caecilia: Brazilian populations of Caecilia gracilis Shaw, 1802 with 9-16 AD, $C$. marcusi Wake, 1985 with 9-17 AD, C. tentaculata with 10-17 AD (Maciel and Hoogmoed 2011); Colombian $C$. pulchraserrana with 12-15 AD (Acosta-Galvis et al. 2019); Central American C. volcani with 14 AD (Taylor 1969). The CP specimen possesses 15 AD (Fig. 2C), which overlaps with some of congeners of $C$. guntheri. For me, this extent of overlapping counts of AD in Caecilia does not interfere with the identification of the CP specimen as $C$. guntheri.

\section{Discussion}

In Ecuador, Caecilia guntheri is distributed in the northwestern lowlands and on the Pacific slopes of the Andes between 70-1800 m a.s.l. (Arteaga et al. 2013). In Colombia, it is found on the Pacific slopes of the western and eastern Andes between 600-1800 m a.s.l. (Lynch 1999; Mueses-Cisneros and Moreno-Quintero 2012). As reported here, $C$. guntheri is also found on the Pacific slope of southeastern Panama. According to the biogeographic patterns in Latin America presented by Morrone (2006), C. guntheri occurs in the biogeographic provinces of Cauca, Western Ecuador, and Chocó.
Presently, it seems that populations of C. guntheri in northern Colombia and eastern Panama have a disjunct distribution, and at a higher level of disjunction if we compare this populations with the populations in southern Colombia and northern Ecuador (Fig. 1). Geographic disjunction may be linked to a lack of lowlands record, especially considering that $C$. guntheri does occur below $100 \mathrm{~m}$ a.s.1. in Ecuador (Arteaga et al. 2013). The discovery of $C$. guntheri in Panama increases the number of caecilian species in Panama to 11 and in Central America to 16 (Jaramillo et al. 2010; Köhler 2011; Johnson et al. 2015; Mata-Silva et al. 2019). The occurrence of this species in Darien is not surprising because the Parque Nacional Darien is an important protected area for regional and global biodiversity (Myers et al. 2000; Deguignet et al. 2014) and has connectivity to South American forests. Given the records of $C$. guntheri in the biogeographic provinces of Cauca, Western Ecuador, and Chocó (Lynch 1999; Mueses-Cisneros and Moreno-Quintero 2012; Arteaga et al. 2013; this report), the new record from CP is an example of the real time of the biotic exchange of caecilian species from South to Central America by the closure of the Isthmus of Panama (Vanzolini and Heyer 1985; Savage and Wake 2001; Pinto-Sanchez et al. 2012).

\section{Acknowledgements}

Fondo Darién provided the financial support for the field trip. Grupo para la Educación y el Manejo Ambiental Sostenible (GEMAS), Fundación Natura and Ministerio de Ambiente de Panamá provided administrative and logistic support. Members of the community Pijibasal in Darien cooperated with logistics and accommodation during the field trip. Maykell Morales and Sean Romaña helped in the field. Universidad de Panamá staff from the Museo de Vertebrados and the Centro para Respuestas en Ofidiología (CEREO) both provided laboratory space. James Menzies, Crystal Kelehear, Jay Savage, and two anonymous reviewers assisted with improvements to the English and in improving of an earlier draft of the manuscript.

\section{References}

Acosta-Galvis A, Torres M, Pulido-Santacruz P (2019) A new species of Caecilia (Gymnophiona, Caeciliidae) from the Magdalena valley region of Colombia. ZooKeys 884: 135-157. https://doi. org/10.3897/zookeys.884.35776

Bustamante-Enríquez LM, Guayasamin JM (2013) The amphibians and reptiles of Mindo: life in the cloudforest. Universidad Tecnológica Indoamérica, Quito, Ecuador, 258 pp.

Deguignet M, Juffe-Bignoli D, Harrison J, MacSharry B, Burgess N, Kingston N (2014) United Nations list of protected areas. UNEPWCMC, Cambridge, UK, 44 pp.

Dunn ER (1942) The American caecilians. Bulletin of the Museum of Comparative Zoology 91: 437-540.

Hijmans RJ, Guarino L, Mathur P (2012) DIVA-GIS version 7.5. University of California, Berkeley, $71 \mathrm{pp}$. http://www.diva-gis.org. Accessed on: 2015-11-11. 
Jaramillo C, Wilson L, Ibáñez R, Jaramillo F (2010) The herpetofauna of Panama: distribution and conservation status. In: Wilson L, Townsend J, Johnson J (Eds.) Conservation of Mesoamerican amphibians and reptiles. $1^{\text {st }}$ edition. Eagle Mountain Publishing, Eagle Mountain, USA, 605-671.

Johnson JD, Mata-Silva V, Wilson LD (2015) A conservation reassessment of the Central American herpetofauna based on the EVS measure. Amphibian \& Reptile Conservation 9 (2): 1-94.

Köhler G (2011) Amphibians of Central America. Herpeton, Offenbach, Germany, 380 pp.

Kubicki B, Arias E (2017) Vulcan's Slender Caecilian, Caecilia volcani, in Costa Rica. Mesoamerican Herpetology 4 (2): 488-492.

Lynch J (1999) Una aproximación a las culebras ciegas de Colombia (Amphibia: Gymnophiona). Revista de la Academia Colombiana de Ciencias Físicas, Exactas y Naturales 23 (suplemento especial): 317-337.

Maciel AO, Hoogmoed MS (2011) Taxonomy and distribution of caecilian amphibians (Gymnophiona) of Brazilian Amazonia, with a key to their identification. Zootaxa 2984 (1): 1-53. https://doi.org/ 10.11646/zootaxa.2984.1.1

Mata-Silva V, De Santis D, Garcia-Padilla E, Johnson J, Wilson L (2019) The endemic herpetofauna of Central America: a casualty of anthropocentrism. Amphibian \& Reptile Conservation 13 (1): 1-64.

Morrone J (2006) Biogeographic areas and transition zones of Latin America and the Caribbean islands based on panbiogeographic and cladistic analyses of the entomofauna. Annual Review of Entomology 51: 467-494. https://doi.org/10.1146/annurev.ento.50.071 803.130447

Mueses-Cisneros J, Moreno-Quintero V (2012) Fauna anfibia de la Reserva Natural Biotopo Selva Húmeda, Barbacoas, Nariño, Colombia. Herpetotrópicos 7 (1-2): 39-54.

Myers N, Mittermeier R, Mittermeier C, Da Fonseca G, Kent J (2000) Biodiversity hotspots for conservation priorities. Nature 403 (6772): 853-858. https://doi.org/10.1038/35002501
Nussbaum R, Hoogmoed M (1979) Surinam caecilians, with notes on Rhinatrema bivittatum and the description of a new species of $\mathrm{Mi}$ crocaecilia (Amphibia, Gymnophiona). Zoologische Mededelingen 54 (14): 217-235.

Pinto-Sánchez NR, Ibáñez R, Madriñán S, Sanjur O, Bermingham E, Crawford AJ (2012) The great American biotic interchange in frogs: multiple and early colonization of Central America by the South American genus Pristimantis (Anura: Craugastoridae). Molecular Phylogenetics and Evolution 62 (3): 954-972. https:// doi.org/10.1016/j.ympev.2011.11.022

Savage JM, Wake MH (2001) Reevaluation of the status of taxa of Central American caecilians (Amphibia: Gymnophiona), with comments on their origin and evolution. Copeia 2001 (1): 52-64. https://doi.org/10.1643/0045-8511(2001)001[0052:rotsot]2.0.co;2

Taylor EH (1968) The caecilians of the world, a taxonomic review. University of Kansas Press, Lawrence, USA, 848 pp.

Taylor EH (1969) A new Panamanian caecilian. The University of Kansas Science Bulletin 48: 187-231. https://doi.org/10.5962/bhl. part.11226

Taylor EH (1973) A caecilian miscellany. The University of Kansas Science Bulletin 50: 187-231. https://doi.org/10.5962/bhl.part.25759

Taylor EH (1974) The caecilians of Ecuador. The University of Kansas Science Bulletin 50: 333-346. https://doi.org/10.5962/bhl.part. 25761

Vanzolini PE, Heyer WR (1985) The American herpetofauna and the interchange. In: Stehli FG, Wake SD (Eds.) The Great American biotic interchange. Plenum Press, New York, USA, 475-487.

Wilkinson M, Nussbaum RA (2006) Caecilian phylogeny and classification. In: Exbrayat JM (Ed.) Reproductive biology and phylogeny of Gymnophiona (caecilians). Science Publishers, Enfield, USA, 39-78.

Wilkinson M, San Mauro D, Sherratt E, Gower DJ (2011) A nine-family classification of caecilians (Amphibia: Gymnophiona). Zootaxa 2874 (1): 41-64. https://doi.org/10.11646/zootaxa.2874.1.3 